
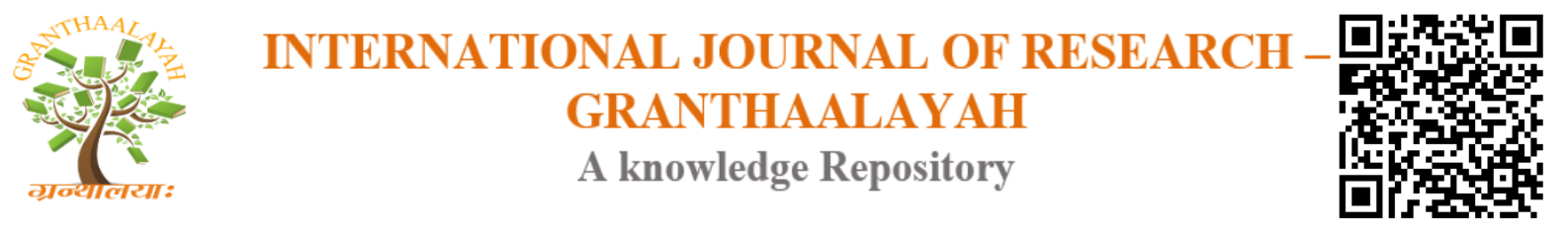

Science

\title{
USE OF CAD FOR APPAREL DESIGNING USING DECORATIVE MOTIFS OF JAMA MASJID
}

\author{
Nandini ${ }^{1}$, Sakshi $^{* 2}$ \\ ${ }^{1}$ M.Sc. Student, Department of Clothing and Textiles, College of Home Science, G.B. Pant \\ University of Agriculture and Technology, Pantnagar, Uttrakhand, India \\ *2 Associate Professor, Department of Clothing and Textiles, College of Home Science, G.B. \\ Pant University of Agriculture and Technology, Pantnagar, Uttrakhand, India
}

\begin{abstract}
Indian has a rich collection of monuments belonging to different periods of history, with motifs of respective periods. These structures are being damaged due to various reasons, in order to preserve the decorative motifs of monuments the present study was planned with an objective to collect the motifs of Jama Masjid, Fatehpur Sikri and apply them on kurti to preserve the motifs and to diversify the product as consumers are demanding for new designs in apparels. The motifs were collected from the site and were used for apparel designing using Corel Draw software. Collected motifs were classified into broad and narrow border design, central design, and buti designs. These were used for designing on kurti using Computer aided designing. The designed products were evaluated by a panel of judges. The judges appreciated the motifs selected for designing and also had an opinion that if such products are available in the market, they will purchase them. The judges also suggested that such products can also be sold at the historical places as tourist visit and can purchase them as the souvenir of that place.
\end{abstract}

Keywords: Jama Masjid; Motifs; Designs; Fatehpur Sikri; Kurti; CAD.

Cite This Article: Nandini, and Sakshi. (2018). "USE OF CAD FOR APPAREL DESIGNING USING DECORATIVE MOTIFS OF JAMA MASJID." International Journal of Research - Granthaalayah, 6(11), 345-349. https://doi.org/10.29121/granthaalayah.v6.111.2018.1137.

\section{Introduction}

Monuments are buildings, statues and other structures which are of historical importance. Monuments include residence of ruler like fort, palaces and garden. It also includes public structure like temple, mosque, bazaar and well etc. The monuments of India had become an inspiration for the future generations with respect to construction technology and designing used. Taj Mahal, Qutub Minar, Jama Masjid, Haumyu Tomb by Mughal kings. Mughal monuments had a combination of Hindu, Islamic and Persian culture. Mughal had built monuments at Delhi, Lahore, Aurangabad, Agra and Fatehpur Sikri. 
Fatehpur Sikri is a town in Agra district of Uttar Pradesh famous for its monuments. Different monuments present in Fatehpur Sikri are Buland Darwaza, tomb of Salim Chishti, Diwan-I-khas, Naubat Khana, Panch Mahal, Birbal's house, Ibadat Khana and Jama Masjid.

Jama Masjid is known as Friday mosque and is the glory of Fatehpur Sikri. It was built in 1571 A.D. by Emperor Akbar. It is one of the largest mosques in India, masjid is rectangular in shape. Masjid marks the phase of transition in Islamic art, as indigenous architectural elements were blended with Persian elements. It was built from red sandstone, with the exceptions that outside of the dome are overlaid with cement. Many decorative designs are carved on the Masjid for ornamentation. The decorative designs present on Jama Masjid have floral, natural, stylized and geometric designs. These designs are getting damaged due to environmental reasons and also due to anthropogenic activities. In order to preserve these motif/designs for future generation documentation of designs is very important. The documented designs can be use as a library of designs and this library can be a source of inspiration to the designers/artisans. Artisans can select the motifs for designing textile by constructional techniques or by surface enrichment technique. These designs are not commonly used in textiles. Introducing these designs in textile can be a way to preserve an Indian culture. We can spread a uniqueness of Indian art to the whole world by this means.

Designer can take source of inspiration from decorative designs present on monuments, and also creating structural decorative design. Adaptation of decorative designs using computer aided designing. Computer aided designing help in visualization and synthesis of designs. Advantages of CAD are it saves time and labour involved in manual work of designing as it is faster.

Motifs craved on stone can be transferred on textiles for preserving these motifs. This will not only preserve these designs and also make person feel affiliated to those places. Designing is field were consumers are demanding new designs in apparels as well as textiles. In recent times, the historical motifs are interpreted in modern and classical styles. Main aim of using these motifs is to introduce diversity and their own cultural identity to the world whilst remaining competition. In order to meet the consumer demand for design and also preserve and transfer the motifs of stone carving of Jama Masjid the present study was planned with the following objectives.

- To collect the decorative designs of Jama Masjid

- To design apparels using motifs.

- To evaluation of its consumer acceptance.

\section{Methodology}

Motifs were collected from Jama Masjid by taking photographs. The motifs were classified as broad border and narrow border designs, central designs and buti for use on apparels. The kurtis were designed using these motifs with the help of Corel Draw software. Kurti was selected as it never goes out of fashion. Designed kurti were evaluated by panel of judges. The data was analyzed statistically. 


\section{Results and Discussions}

The motifs were selected from Jama Masjid for applying on kurti. Total three motifs each were selected in broad border and narrow border design, central design and buti design for use on kurti. Table 1 illustrates the motifs selected for designing.

Table 1: Motifs selected from Jama Masjid

\begin{tabular}{|c|c|c|c|}
\hline $\begin{array}{l}\text { Category } \\
\text { of design }\end{array}$ & Motif 1 & Motif 2 & Motif 3 \\
\hline $\begin{array}{l}\text { Broad } \\
\text { border } \\
\text { design }\end{array}$ & & & \\
\hline $\begin{array}{l}\text { Central } \\
\text { design }\end{array}$ & & & \\
\hline $\begin{array}{l}\text { Buti } \\
\text { design }\end{array}$ & & & \\
\hline $\begin{array}{l}\text { Small } \\
\text { border } \\
\text { design }\end{array}$ & & & \\
\hline
\end{tabular}

It is clear from the Table 1 that all motifs were selected were geometrical, stylized floral and creeper designs. In most of Mughal buildings floral and creeper designs are seen this may be due to their love towards nature and they also built gardens.

Table 2 shows information regarding kurti designs prepared on CorelDRAW software using combination of broad and narrow border design, central design and buti design. Six kurtis were designed using combination of selected border, buti and central design. These designs were arranged to create designs on kurti. While applying design current trend was kept in mind. Design I had combination of narrow and broad border, which shows the possibility of applying border design for designing kurti. Design II had combination of buti and narrow border, where buti were arranged in brick repeat. Design III had combination od cxentral design, buti and narrow border. Central design and buti were used for designing kurti which as named as Design IV. Combination 
of broad border and buti can be seen in Design V. Design VI had combination of buti, central design and broad border. These designs were evaluated by panel of judges and they gave rank to the designs. The judges were female students of G. B. Pant University of Agriculture and Technology, Pantnagar who wear kurti normally.

Table 2: Designing of kurtis using combination of motifs

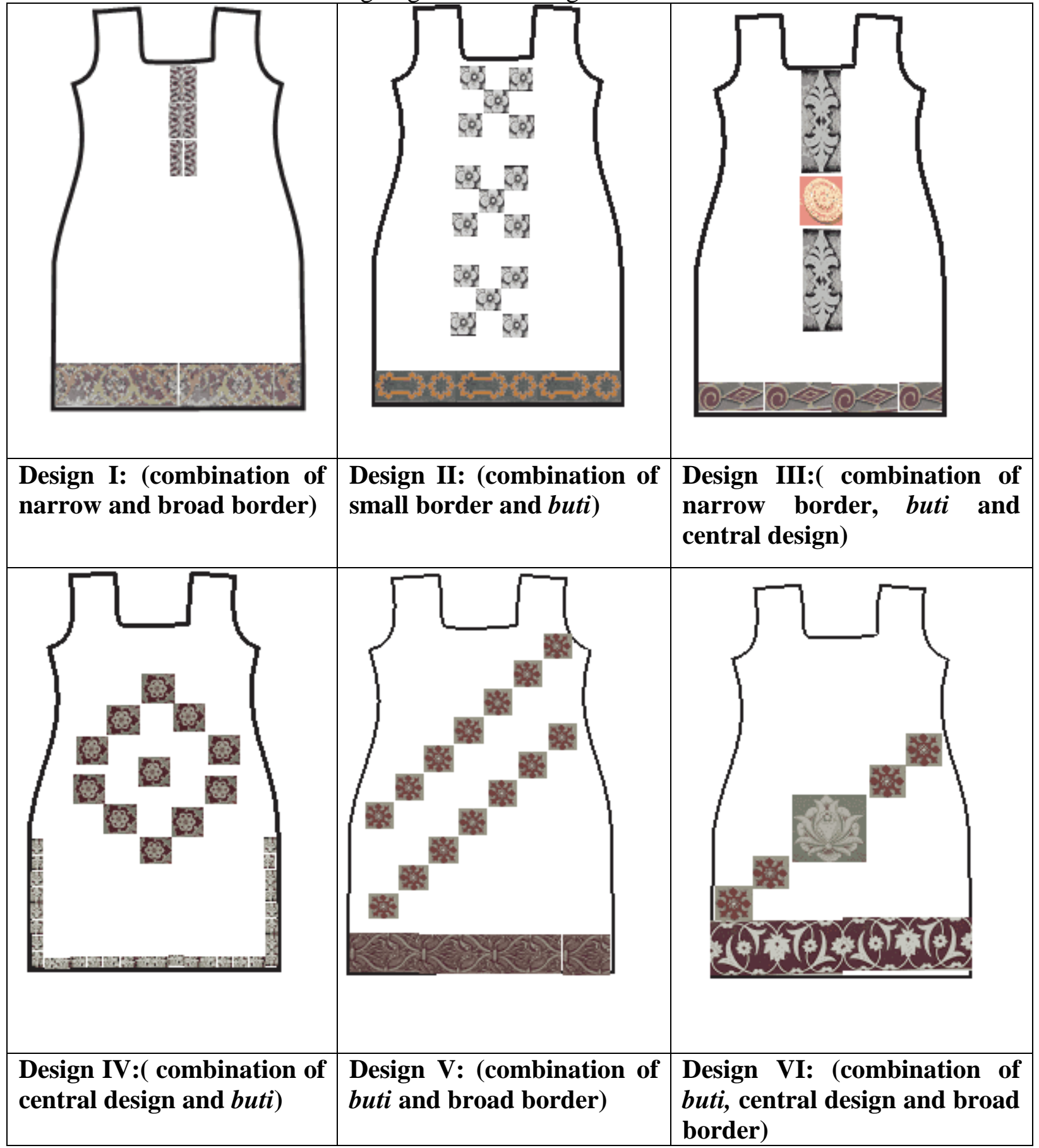

The results of the judgment showed that Design II secured first rank which had combination of small border and buti design, followed by Design I (combination of narrow and broad border) 
which got second ranking. Design $\mathrm{V}$ held third rank which had combination of buti and broad border. Design III got fourth rank, both design IV and VI got fifth rank. Judges appreciated the designs.

Similar type of work is done by Bora and Sakshi (2017) where they have designed apparel using traditional gond painting motifs.

\section{Conclusion}

The architectural motifs from various famous places can be used for creating textile and apparel design through $\mathrm{CAD}$. The motifs can be arranged to produce various design combinations. These designs can be applied on fabric by block printing, screen printing, digital printing, weaving, embroidery etc. This type of study will not only retain the motifs of the monuments but also preserve them as they are transferred to other medium like fabric. The judges appreciated the products. The judges appreciated the motifs selected for designing and also had an opinion that if such products are available in the market, they will purchase them. The judges also suggested that such products can also be sold at the historical places as tourist visit and can purchase them as the souvenir of that place.

\section{References}

[1] Bora S., and Sakshi,. Designing of apparel using traditional gond painting motif. International Journal of Home Science. Vol.3, No.1, 2017, 304-309.

[2] Gahlot M., and Naik S., Principles of Design and Application. http://ecoursesonline.iasri.res.in/. 2012. Retrieved on June 4, 2017.

[3] Monument Structure with Emperor Name. 2018. https://www.google.co.in/ search. Monuments ofmughal-empire-with names \& source Retrieved on June 7, 2018.

[4] Nath R., History of Mughal Architecture, Vol. IV. Delhi. Motilal Banarsidas Publication; 1978, $390 \mathrm{p}$.

[5] Nath R., History of Mughal Architecture, Vol. II. New Delhi. Abhinav Publications; 1985, 345 p.

[6] Nath R., Architecture of Fatehpur Sikri, 1st ed. Jaipur. Abhinav Publication; 1988, 290 p.

[7] Sarkar J., Computer Aided Design: A Conceptual Approach, New York, CRC Press; 2015, 739 p.

*Corresponding author.

E-mail address: sakshi_ct@ rediffmail.com 